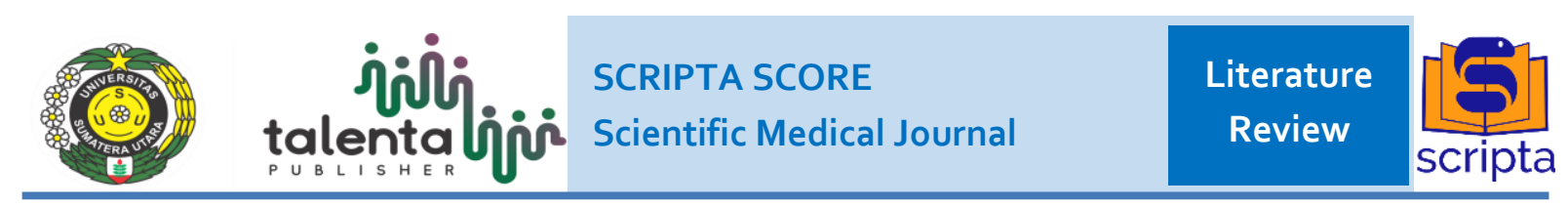

\title{
The Potential of eCD4-Ig, Delivered by Adeno-Associated Virus (AAV) Vector as a Novel Vaccine for HIV/AIDS Infection
}

\author{
Ghea Mangkuliguna \\ School of Medicine and Health Sciences, Atma Jaya Catholic University of Indonesia, Jakarta
}

\begin{abstract}
Background: HIV/AIDS has already become one of the world's major health issues taking its toll on millions of lives each year. Developing an HIV vaccine with excellent efficacy has become a global urgency that must be addressed immediately. Recently, researchers have successfully developed a more self-like molecule which is a fusion protein between human CD4 domains and immunoglobulin $\mathrm{G}$ (IgG) Fc with a CCR5-mimetic sulfopeptide in the carboxy terminus. This molecule, eCD4-Ig, targets only the conserved regions of HIV Env and thus demonstrated the most remarkable potency and breadth so far. By using adeno-associated virus (AAV) vector, eCD4-Ig's long-term expression in vivo can be achieved. Objectives: Evaluate the efficacy of AAV-eCD4-Ig as both preventive and therapeutic vaccine for HIV/AIDS infection. Methods: A systematic literature study was conducted with the database in PubMed, ScienceDirect, and Proquest. No time and language restriction were applied. Discussion: This review shows that eCD4-Ig eliminates HIV-infected cells through neutralization and antibody-dependent cell-mediated cytotoxicity (ADCC). Moreover, eCD4-Ig is also capable of preventing HIV infection in vivo. Delivered with AAV, eCD4-Ig is maintained stably at both protective and therapeutic levels, as well as gives robust protection for rhesus macaques for almost a year long through a single injection. Conclusion: This study offers evidences that AAVeCD4-Ig appears to have the potential to be an effective vaccine to prevent HIV infection.
\end{abstract}

Keywords: AAV, AIDS, eCD4-Ig, HIV, vaccine

\section{ABSTRAK}

Latar Belakang: Pengembangan vaksin HIV yang efektif menjadi sangat penting mengingat tingginya angka kematian yang ditimbulkan oleh HIV/AIDS. Beberapa tahun terakhir, peneliti berhasil menemukan sebuah molekul yang tersusun atas domain CD4 manusia, immunoglobulin $G(\operatorname{Ig} G) F c$, dan sulfopeptida yang menyerupai CCR5. Molekul yang dinamakan eCD4-Ig ini menargetkan area konservatif dari HIV Env sehingga berpotensi untuk menjadi vaksin HIV yang efektif. Ekspresi eCD4Ig akan dipertahankan menggunakan Adeno-associated Virus Vector (AAV). Tujuan: Evaluasi efektivitas AAV-eCD4-Ig sebagai vaksin untuk HIV/AIDS. Metode: Penelitian dilakukan dengan melakukan tinjauan pustaka dari beberapa database jurnal, yakni PubMed, ScienceDirect, dan Proquest tanpa ada batasan waktu dan bahasa. Pembahasan: eCD4-Ig membunuh sel-sel yang terinfeksi HIV melalui proses netralisasi dan antibody-dependent cell-mediated cytotoxicity (ADCC). eCD4-Ig juga memberikan perlindungan terhadap infeksi HIV. Ekspresi AAV-eCD4-Ig sangat stabil untuk dosis protektif dan terapeutik, sekaligus melindungi rhesus macaques dari infeksi HIV selama hampir 1 tahun lamanya hanya dengan sekali injeksi. Kesimpulan: AAV-eCD4-Ig memiliki potensi yang menjanjikan untuk menjadi vaksin HIV yang efektif bagi seluruh penderita HIV/AIDS di seluruh dunia.

Kata Kunci: AAV, AIDS, eCD4-Ig, HIV, vaksin

Received [30 Apr 2020] | Revised [17 Nov 2020] | Accepted [18 Nov 2020]

\section{INTRODUCTION}

Human immunodeficiency virus (HIV) is a virus that attacks humans' immune system. This highly contagious virus specifically targets the $\mathrm{CD} 4^{+} \mathrm{T}$ cells and later destroys the entire cells colonies. If left untreated, the number of $\mathrm{CD}^{+} \mathrm{T}$ cells will continue to decline rendering the immune system incapable of fighting off 
infection - a condition known as acquired immunodeficiency syndrome (AIDS). ${ }^{[1,2]}$

HIV/AIDS has become a worldwide major health issue. According to World Health Organization (WHO) and Joint United Nations Programme on HIV/AIDS (UNAIDS), there were approximately 37.9 million people worldwide living with HIV/AIDS in 2018. ${ }^{[2,3]}$ Since the beginning of the AIDS epidemic, HIV has claimed more than 32 million of lives globally. ${ }^{[2]}$

For the last few decades, the medicine used for treating HIV/AIDS is called antiretroviral therapy (ART). It does not cure HIV infection, but only suppress viral load temporarily. ${ }^{[4-7]}$ In 2018, WHO reported that 23.3 million people $(62 \%)$ living with HIV/AIDS are currently receiving ART. ${ }^{[2]}$ ART as the current HIV therapy is necessary, but not competent enough to end the global AIDS epidemic.

In the early years of the AIDS epidemic, immunotherapy against HIV-1 was developed. Human monoclonal antibodies $(\mathrm{mAb})$ appear to shed light on HIV/AIDS therapy. Treatment with mAb showed a slight improvement than the previously used therapies. However, mAbs had limited breadth against multiple HIV-1 strains. ${ }^{[8,9]}$

Several years after the discovery of $\mathrm{mAB}$, researchers have tried to transfer antibodies from the sera of HIV-infected subjects to AIDS patients. Unfortunately, these antibodies were ineffective against the diverse and highly adaptive virus. ${ }^{[5]}$ However, studies demonstrated that 20$50 \%$ of chronically HIV-infected individuals could produce antibodies that target shared epitopes across various clades of HIV - later known as broadly neutralizing antibodies (bNAbs). ${ }^{[4,5,9,10]}$

Since then, multiple bNAbs targeting different HIV envelope glycoprotein (Env) had been identified. The best ones ever found, N6 and 10E8, manage to neutralize $98 \%$ of HIV strains with $50 \%$ inhibitory concentration $\left(\mathrm{IC}_{50}\right)$ up to 50 $\mu \mathrm{g} / \mathrm{mL} \cdot{ }^{[5,6,8,9,11]} \quad$ Although seems promising, however, developing a potent and broad bNAb requires excessive mutation of antibody genes. ${ }^{[7]}$ Thus, the newly-formed bNAbs are frequently subjected to the host's immune system inducing the formation of anti-drug antibodies (ADA) - that further decrease their efficacy even more. ${ }^{[7,12-15]}$

In order to ensure neutralization of HIV, excellent potency and breadth is a necessity for developing an effective HIV vaccine. At the same time, it should maintain a low immunogenicity profile when administered to humans. Considering this, researchers have begun to explore the possibility of molecules resembling antibodies that could recognize HIV conserved epitopes. Recently, researchers have successfully developed a fusion protein which functions like an antibody. This more self-like molecule is a fusion between human CD4 domains and immunoglobulin $\mathrm{G}(\mathrm{IgG}) \mathrm{Fc}$ with a CCR5mimetic sulfopeptide in the carboxy terminus. ${ }^{[11,12,16,17]}$ This molecule, eCD4Ig, targets only the conserved regions of HIV Env and thus demonstrated the most remarkable potency and breadth so far.

Besides being potent and broad, eCD4-Ig's long-term expression in vivo must be maintained at protective and therapeutic levels. This response can be achieved by using adeno-associated virus (AAV) vector. AAV-expressed eCD4-Ig is maintained stably for almost a year-long through a single injection. ${ }^{[11,12,16]}$

Therefore, this study is conducted to highlight the efficacy of eCD4-Ig, delivered with AAV vector, as both preventive and therapeutic vaccine for HIV/AIDS infection.

\section{METHOD}

\section{Data Sources and Search}

A systematic literature study was conducted with the database in PubMed, ScienceDirect, and Proquest. No time and language restriction were applied. The keywords used are described as follow: 
"eCD4-Ig" AND "HIV" OR "human immunodeficiency virus" OR "AIDS" OR "acquired immunodeficiency syndrome". The results from the literature search were first reviewed by reading the titles and abstracts. The relevant studies were further checked by reading the full texts and assessed for inclusion. Search in electronic database yielded 323 studies. Screening through titles and abstracts found 32 articles, 9 of which met the eligibility criteria of current study. Search in electronic database yielded 323 studies. Screening through titles and abstracts found 32 articles, 9 of which met the eligibility criteria of current study.

\section{Eligibility Criteria}

The following criteria are considered for studies' eligibility: type of studies, problem, intervention, comparison, outcome (PICO).

Type of Studies. Randomisedcontrolled trials are included for this study. Identified articles included humans and non-humans' studies. Cross-sectional, case control, cohort, case report, case series, conference abstracts, expert opinion, and review papers are excluded. Articles with unavailable full-text, languages other than English, and irrelevant topics are also omitted.

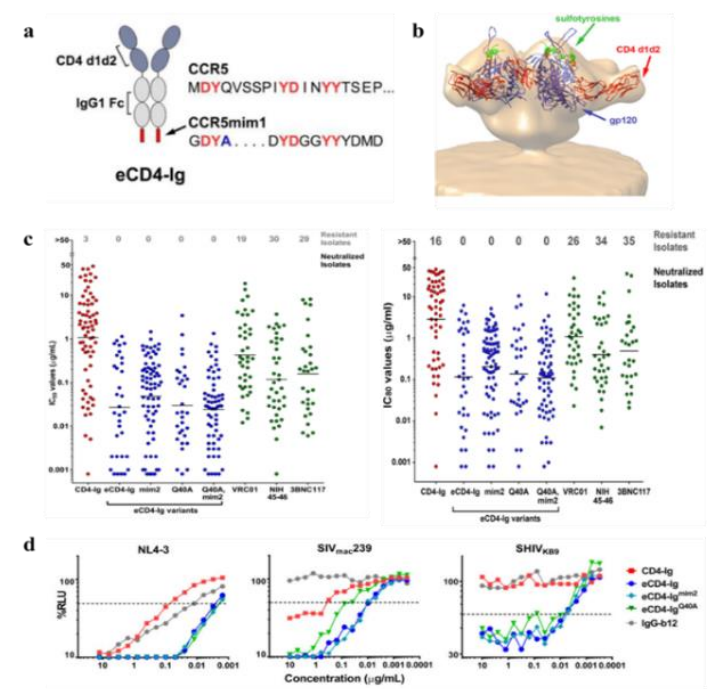

Figure 1. Structure (a,b) and Capabilities of eCD4-Ig in Neutralizing HIV Strains (c) and Enhancing ADCC (d) ${ }^{[16]}$
Population. All subjects (humans or non-humans) challenged with infectious doses of HIV are included for this study.

Intervention. Studies evaluating the efficacy of eCD4-Ig to neutralize HIVinfected subjects are included. In addition, included studies also evaluate AAVeCD4-Ig to protect subjects from HIV infection.

Comparison. Included studies compared HIV-infected subjects inoculated with and without eCD4-Ig to evaluate the efficacy at both therapeutic and preventive level.

Outcome: The key findings of included studies are the number of subjects fully protected from HIV infection.

\section{DISCUSSION}

eCD4-Ig as a Promising Broad and Potent Neutralizing Agent against HIV Infection

Current trend in HIV/AIDS treatment is only limited to the suppression of viral load temporarily by using ART. The therapy developed for the last few decades focuses on targeting HIV Env by using bNAbs. Despite the promising potency and breadth, bNAbs still have a major drawback regarding of immunogenicity. Considering this, researchers have shifted their focus on using a more self-like molecule to target the conserved regions of HIV Env. ${ }^{[8,11]}$

Recently, researchers have successfully engineered eCD4-Ig, a Fcfusion protein between domains 1 and 2 of human CD4 and IgG Fc with CCR5mimetic sulfopeptide attached in the carboxy terminus (Figure 1a). eCD4-Ig cooperatively binds to the CD4- and coreceptor-binding sites (Figure 1b) on all HIV subtypes hence its markedly superior potency and breadth. ${ }^{[12,16,17]}$

eCD4-Ig eliminates HIV-infected cells through 2 main mechanisms: neutralization and antibody-dependent cell-mediated cytotoxicity (ADCC). ${ }^{[12,16,18]}$ eCD4-Ig engages the Env and potently 
neutralizes the highly diverse HIV isolates. According to an in vitro study by Gardner et al., eCD4-Ig neutralized $100 \%$ of HIV1, HIV-2, and SIV strains with $\mathrm{IC}_{50}$ and $\mathrm{IC}_{80}$ less than $1.5 \mu \mathrm{g} / \mathrm{mL}$ and $10 \mu \mathrm{g} / \mathrm{mL}$, respectively (Figure 1c). ${ }^{[16]}$ This finding is supported by another study done by Fetzer et al. which has shown the excellent potency of eCD4-Ig and its variants in neutralizing diverse HIV-1 isolates. ${ }^{[17]}$

In addition of enhancing neutralization, CCR5-mimetic sulfopeptides ensure no viral escape and HIV-infection occurring in CD4-negative cells. ${ }^{[11,16,19,20]}$ According to the study by Fellinger et al., eCD4-Ig was capable of altering HIV-1 Envs, hence making the viruses less infectious and more sensitive to antibodies present in the serum of HIVinfected people. ${ }^{[20]}$ Other studies done by Davis-Gardner et al. and Fetzer et al. also supported this finding. eCD4-Ig has the ability to expose the V3-loop of HIV Env hence its ability to enhance the potency of V3-loop antibodies, which are abundant but non-neutralizing in HIV-infected individuals. ${ }^{[18,21]}$

The remarkable potency of eCD4-Ig also comes from its ability in mediating ADCC. An in vitro study by DavisGardner et al. revealed that eCD4-Ig mediated killing of HIV-infected cells up to 10 times more efficiently by natural killer (NK) cells. ${ }^{[18]}$ This finding is supported by another study by Gardner et $a l$. It is revealed that eCD4-Ig enhanced ADCC activity by 30-40 times higher when tested against diverse HIV tropisms (Figure 1d). ${ }^{[16]}$ Moreover, eCD4-Ig could alter the conformation of HIV Env so that pre-existing non-neutralizing antibodies in patients' sera could bind to HIV Env and promote ADCC activity by 100 -fold. ${ }^{[18]}$

Besides having a remarkable therapeutic effect, eCD4-Ig is also proven to be capable of preventing HIV infection. An in vivo study by Gardner et al. revealed that eCD4-Ig fully protected humanized $\mathrm{NOD} / \mathrm{SCID} / \gamma \mathrm{c}$ (NSG) mice infected with $5 \times 10^{4}$ infectious units of HIV $_{\text {NL4-3. }}$
Complete protection was achieved at the concentration of $2-4 \mu \mathrm{g} / \mathrm{mL}$ and maintained up to 5 weeks after inoculation. ${ }^{[16]}$ Moreover, the more selflike structure of eCD4-Ig makes it less likely subjected to endogenous antibodies that can impair the efficacy. Even the additional CCR5-mimetic sulfopeptides do not elicit significant antibody responses. ${ }^{[12,16,19]}$ These findings strongly suggested eCD4-Ig as a promising candidate for HIV vaccine development.

eCD4-Ig Delivered by Adeno-associated Virus Vector (AAV-eCD4-Ig) as a Promising Novel Vaccine for HIV Infection

Another important issue in developing an effective vaccine for HIV/AIDS is the use of an appropriate packaging system to ensure eCD4-Ig's expression at protective and therapeutic levels. Previously, antibodies or antibody-like inhibitors were passively administered. However, this method prompted the need of repeated infusion which could lower patient's compliance. ${ }^{[2,23]}$ This approach is deemed inefficient and thus an alternative is needed to express biologically active molecules in a prolonged manner with a single inoculation. In this case, AAV vector appears to be a major breakthrough of this problem.

Adeno-associated virus (AAV) is a small $(20 \mathrm{~nm})$, non-enveloped virus. It belongs to genus Dependoparvovirus, which in turn belonging to family Parvoviridae. ${ }^{[22]}$ AAV vector-mediated gene transfer has gained a lot of attention as it is able to express desired-protein for the lifetime of the cell as long as the product is considered as self by one's immune system. ${ }^{[23]}$ AAV particles also show high resistance to high temperature and widely-range $\mathrm{pH}$, as well as stability after being stored for a long time. ${ }^{[22,23]}$ Therefore, this paper strongly suggest the use of AAV to efficiently deliver eCD4-Ig (AAV-eCD4-Ig) both as a prevention and treatment for HIV infection. 

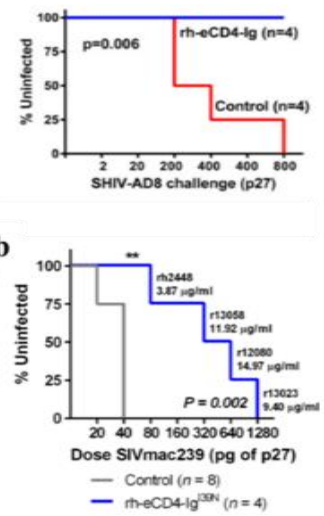
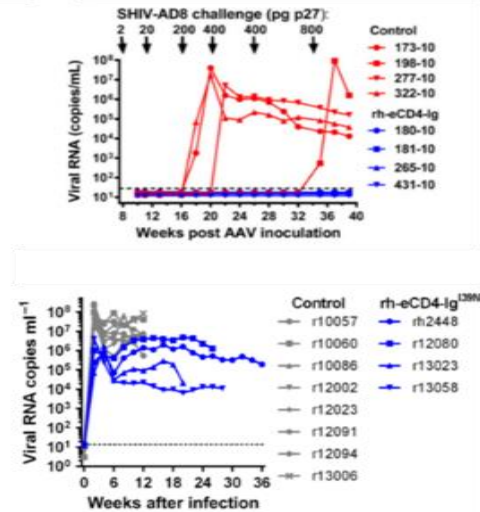
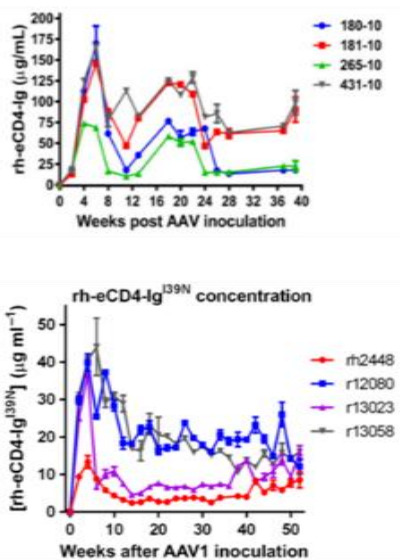

Figure 2. AAV-eCD4-Ig Promotes Full Protection of Rhesus Macaques from SHIV-AD8 (a) and SIVmac239 Infection ${ }^{[12,16]}$

AAV-eCD4-Ig can give full protection from HIV infection in nonhuman studies. According to a study by Gardner et al. in 2015, AAV-eCD4-Ig completely protected four of four rhesus macaque from six escalating doses of simian-human immunodeficiency virus (SHIV-AD8) infection. A single administration of $2.5 \times 10^{13}$ genomic copies (GCs) of AAV-eCD4-Ig was capable of maintaining stable eCD4-Ig expression between $17-77 \mu \mathrm{g} / \mathrm{mL}$ and giving robust protection for inoculated macaques up to 40-week long (Figure 2a). ${ }^{[16]}$ Another study by Gardner et al. in 2019 revealed that AAV-eCD4-Ig was capable of preventing SIVmac239 infection in four of four inoculated macaques with serum concentration as low as $3-18 \mu \mathrm{g} / \mathrm{mL}$ by the end of week-50 (Figure 2b). ${ }^{[12]}$ These studies highlight the potential of AAV to achieve a long-term and stable transgene delivery in humans' bodies, particularly in HIV-infected individuals. The delivery of eCD4-Ig is boosted to a point where its effectivity reaches beyond average.

\section{CONCLUSION}

The extensive genetic diversity in HIV has been a challenge to develop an effective HIV vaccine. Recently, eCD4-Ig has been developed and proven to be the most potent and broad therapy at present. At a low concentration, eCD4-Ig is able to neutralize $100 \%$ of HIV-1, HIV-2, and
SIV strains. It also mediates efficient killing by NK cells. In addition, the selflike eCD4-Ig is less likely targeted by preexisting antibodies. This review revealed that one-time administration AAV-eCD4Ig fully protected test subjects from HIV infection for at least a year. Thus, AAVeCD4-Ig appears to have the potential to be an effective vaccine to prevent HIV infection.

\section{RECOMMENDATIONS}

Further comprehensive studies should be done to assess the efficacy of AAVeCD4-Ig in vitro and in vivo, as it would serve as a foundation for future management of HIV/AIDS infection. Moreover, it is recommended that clinical trials are iniated to investigate the ability of AAV-eCD4-Ig in giving protection and treatment for HIV-infected patients.

\section{REFERENCES}

[1] CDC. HIV/AIDS [Internet]. Atlanta, GA: Center for Disease Control and Prevention; 2019 [cited 2019 Aug 20]. Available from: https://www.cdc.gov/hiv

[2] WHO. HIV/AIDS [Internet]. Geneva: World Health Organization; 2019 [cited 2019 Aug 20]. Available from: https://www.who.int/newsroom/fact-sheets/detail/hiv-aids 
[3] UNAIDS. AIDSinfo [Internet]. Geneva: Joint United Nations Programme on HIV/AIDS; 2019 [cited 2019 Aug 04]. Available from: https://aidsinfo.unaids.org/

[4] Gama L, Koup RA. New-generation high-potency and designer antibodies: role in HIV-1 treatment. Annu Rev Med. 2018;69:14.1-14.11. doi: 10.1146/annurev-med-061016$\underline{041032}$

[5] Burton DR, Hangartner L. Broadly neutralizing antibodies to HIV and their role in vaccine design. Annu Rev Immunol. 2016;34:635-59. doi: 10.1146/annurev-immunol-041015$\underline{055515}$

[6] Stephenson KE, Barouch DH. Broadly neutralizing antibodies for HIV eradication. Curr HIV/AIDS Rep. 2016;13:31-7. doi: 10.1007/s11904-016-0299-7

[7] Sahay B, Nguyen CQ, Yamamoto JK. Conserved HIV Epitopes for an Effective HIV Vaccine. J Clin Cell Immunol. 2017;8(4):518. doi: 10.4172/2155-9899.1000518

[8] Padte NN, Yu J, Huang Y, Ho DD. Engineering multi-specific antibodies against HIV1. Retrovirology. 2018;15(1):60. doi: 10.1186/s12977-018-0439-9

[9] Ferrari G, Haynes BF, Koenig S, Nordstorm JL, Margolis DM, Tomaras GD. Envelope-specific antibodies and antibody-derived molecules for treating and curing HIV infection. Nat Rev Drug Discov. 2016;15(12):823-34. doi: 10.1038/nrd.2016.173

[10] Hraber P, Seaman MS, Bailer RT, Mascola JR, Montefiori DC, et al. Prevalence of broadly neutralizing antibody responses during chronic HIV-1 infection. AIDS. 2014; 28(2):163-69. doi: 10.1097/QAD.0000000000000106

[11] Gardner MR, Farzan M. Engineering antibody-like inhibitors to prevent and treat HIV-1 infection. Curr Opin
HIV AIDS. 2017;12(3):294-301. doi: 10.1097/COH.0000000000000367

[12] Gardner MR, Fellinger $\mathrm{CH}$, Kattenhorn LM, Davis-Gardner ME, Weber JA, Alfant B, et al. AAVdelivered eCD4-Ig protects rhesus macaques from high-dose SIVmac239 challenges. Sci Transl Med. 2019 Jul 24;11(502). doi: 10.1126/scitranslmed.aau5409

[13] Gardner MR, Fetzer I, Kattenhorn LM, Davis-Gardner ME, Zhou AS, Alfant B, et al. Anti-drug Antibody Responses Impair Prophylaxis Mediated by AAV-Delivered HIV-1 Broadly Neutralizing Antibodies. Mol Ther. 2019;27(3):650-60. doi: 10.1016/j.ymthe.2019.01.004

[14] Falkenhagen A, Joshi S. HIV Entry and Its Inhibition by Bifunctional Antiviral Proteins. Mol Ther Nucleic Acids. 2018;13:347-64. doi: 10.1016/j.omtn.2018.09.003

[15] Martinez-Navio JM, Fuchs SP, Pedreño-López S, Rakasz EG, Gao $\mathrm{G}$, et al. Host anti-antibody responses following adenoassociated virus-mediated delivery of antibodies against HIV and SIV in rhesus monkeys. Mol Ther. 2016:24;76-86. doi: $10.1038 / \mathrm{mt} .2015 .191$

[16] Gardner MR, Kattenhorn LM, Kondur HR, et al. AAV-expressed eCD4-Ig provides durable protection from multiple SHIV challenges. Nature. 2015;519(7541):87-91. doi: 10.1038/nature14264

[17] Fetzer I, Gardner MR, DavisGardner ME, Prasad NR, Alfant B, Weber JA, et al. eCD4-Ig Variants That More Potently Neutralize HIV1. J Virol. 2018 Jun 15;92(12):e02011-17. doi: 10.1128/JVI.02011-17

[18] Davis-Gardner ME, Gardner MR, Alfant B, Farzan M. eCD4-Ig promotes ADCC activity of sera 
from HIV-1-infected patients. PLoS Pathog. 2017;13(12):e1006786. doi: 10.1371/journal.ppat.1006786

[19] Quinlan BD, Joshi VR, Gardner MR, Ebrahimi KH, Farzan M. A doublemimetic peptide efficiently neutralizes HIV-1 by bridging the CD4- and coreceptor-binding sites of gp120. J Virol. 2014;88(6):3353-8. doi: 10.1128/JVI.03800-13

[20] Fellinger $\mathrm{CH}$, Gardner MR, Weber JA, Alfant B, Zhou AS, Farzan M. eCD4-Ig Limits HIV-1 Escape More Effectively than CD4-Ig or a Broadly Neutralizing Antibody. J Virol. 2019 Jun 28;93(14). doi: 10.1128/JVI.00443-19

[21] Fetzer I, Davis-Gardner ME, Gardner MR, et al. A CoreceptorMimetic Peptide Enhances the Potency of V3-Glycan Antibodies. J Virol. 2019;93(5):e01653-18. doi: 10.1128/JVI.01653-18

[22] Brady JM, Baltimore D, Balazs AB. Antibody gene transfer with adenoassociated viral vectors as a method for HIV prevention. Immunol Rev. 2017;275:324-33. doi: $\underline{10.1111 / \mathrm{imr} .12478}$

[23] Fuchs SP, Desrosiers RC. Promise and problems associated with the use of recombinant AAV for the delivery of anti-HIV antibodies. Mol Ther Methods Clin Dev. 2016;3:16068. doi: $\underline{10.1038 / \mathrm{mtm} .2016 .68}$ 